ISSN No. 0974-035X

An indexed refereed \& peer-reviewed journal of higher education

Towards Excellence

UGC-HUMAN RESOURCE DEVELOPMENT CENTRE

Gujarat University, Ahmedabad-380009, Gujarat, India

\title{
ARE YOU LOYAL IF SATISFIED WITH MEAL OUTSIDE ? : A RELATION BETWEEN CUSTOMER SATISFACTION AND LOYALTY IN RESTAURANTS.
}

\author{
Dr. J. M. Badiyani
}

\begin{abstract}
$\underline{\text { Abstract }}$
The restaurants business is growing at it's own pace in the world as well as in India. This paper examines the relationship of customer satisfaction and customer loyalty among customers of restaurants in Gujarat state of India. Various factors are used to measured customer satisfaction and customer loyalty among customers of restaurants via a structured questionnaire. A sample of 381 respondents using convenience sampling was surveyed. The analysis is done using descriptive analysis, pearson correlation coefficient, linear regression analysis, $t$ test and ANOVA test. The positive correlation is found between customer satisfaction and customer loyalty and thus, coefficients of regression and adjusted $\mathrm{R}^{2}$ are calculated. Among demongraphics, gender, age and income groups have shown a significant difference of customer satisfaction and customer loyalty while education groups didn't show a significant difference of customer satisfaction and customer loyalty. Females are more satisfied and loyal compared to males while less than 25 years of age group is the most satisfied and loyal among all age groups. As income increases the satisfaction and loyalty decreases upto the yearly income of rs. 12,00,000. For formulating marketing strategies, further research is required but, the research has thrown light on relationship and demographic group comparisons and may be helpful for marketers and further researchers.
\end{abstract}

Key words : restaurants, customer satisfaction, customer loyalty, demographic groups, regression, model.

\section{Introduction.}

A restaurant is a business that prepares and serves food and drinks to customers ( Wikipedia.org, 2020 ). The restaurants can be vegetarian or non vegetarian. The restaurant can be classified by cuisine too like Indian, Japanese, Italian, American etc.. The restaurants can be very expensive ones which may be attached to luxury hotels or very inexpensive street food servings. A wide variety of food in restaurants throughout the country is available in India. The restaurant business in the world 
was \$ 3.4 trillion in 2018 and is expected to reach $\$ 4.2$ trillion by 2024 ( prnewswire.com, 2020 ). In 2016, the restaurant industry's market size in U. S. was $\$ 782$ billion. India was on $4^{\text {th }}$ position with market size of \$ 148 billion ( statistica.com, 2020 ). Restaurant business in India is the largest service sector in India after retail and insurance and is 20 times of the film industry, 4.7 times of hotels and 1.5 times of the pharmaceutical sector ( limetray.com, 2020 ). The ever growing restaurant field faces competition and competition generated the need for loyalty for restaurants. The customer satisfaction and customer loyalty are related with each other rather, customer satisfaction can bring customer loyalty.

\section{Review of literature.}

The fulfilment of expectations and level of joy is termed as satisfaciton in a study ( Zairi, 2000 ). The consumer satisfaction and loyalty will come after the choice of the restaurants. In a study, ( Lewis, 1981 ) found out 3 types of restaurants i. e. Family, atmosphere and gourmet for choice decisiosn. The choice factors included (Auty, 1992 ) celebrations, social occations, convenience or quick dines and business dines. Various factors affecting consumer choice and satisfaction are impacting them include quality of food ( Knutson and Patton, 1993, Soriano, 2002 ), price ( Voss, Parasuraman and Grewal, 1998 ), ingredients and preparation including nutritional values ( Bailey and Tian, 2002, Mill 2007 ), menu style and newness ( Hensley and Sulek, 2004, Jang and Namkung, 2007 ), expensiveness i. e. more expensive more quality ( Muller and Woods, 1994 ), ambience, facilities and comfort ( Kivela, 1997, Wakefield and Blodgett, 1994 ), brand credibility ( O’Shaughnessy, 1971, Sweeney and Swait, 2008 ), "green" restaurants ( Hu, 2012, Hu, Parsa and Self, 2010 ), staff consumer relations and relationship quality ( Jones and Merricks, 1996, Jin et. al., 2013 ) etc..

Loyalty of consumers is a commitment to a brand, a store, a style, a pattern etc. which repeats. Loyalty depends on the psychological construct of the person ( Olson and Jacoby, 1971 ). There are various studies on relationships of loyalty in restaurants with consumer satisfaction ( Cengiz et. al., 2007, Eakuru and Mat, 2008, Han and Ryu, 2009 ), which indicated repurchase and price tolerance ( Fornell and Larcker, 1996 ). Consumer satisfaction leads to revisit of the restaurant. ( Gupta, McLaughlin and Gomez, 2007, Sulek and Hensley, 2004; Soderlund and Ohman, 2005, Cheng, 2005 ). Fornell et al. (1996) indicated that enhancing satisfaction level contributed to building customer loyalty in regards to the repurchase likelihood and price tolerance given repurchase. In addition, Han and Ryu (2009) found that that the direct effect of customer satisfaction on customer 
loyalty was statistically significant. Repurchase is easier than first time in imagination of ambience and food ( Petrick, 2004 ). In addition to service orientation and service quality, customer satisfaction is playing a vital role in customer loyalty ( Kim, 2011 ). The relationship of customer satisfaction and customer loyalty can become a research gap for Gujarat, India as upto the best of the knowledge of the researcher, the customer satisfaction and customer loyalty in Gujarat state of India is less studied.

\section{Objectives and methods.}

The research gap of observing the relationship between customer satisfaction and customer loyalty of customers of restaurants in Gujarat are studied and following objectives are formed out of the study.

1. To identify factors affecting customer satisfaction and customer loyalty among customers of restaurants.

2. To observe customer satisfaction and customer loyalty among customers of restaurants.

3. To study relationship between customer satisfaction and customer loyalty among customers of restaurants.

4. To compare customer satisfaction and customer loyalty among customers of restaurants for various demographic groups like gender, age, education and income.

Here, the consumer satisfaction is measured through a set of 18 factors classified in 6 categories ( Badiyani, 2018 ). For measuring loyalty, a scale comprising of 3 factors of loyalty was used ( Sapic et. al., 2018 ). The factors for measuring customer satisfaction includes taste of the food, variety of food, new menu items, craveability, cleanliness, healthy food, freshness of food, music, decoration and overall environment, larger area for kids and others, price, proximity of the restaurant, offers by restaurants, prestige of the restaurant in the area, choice or opinion of reference group, personal choice and other factors, service and behaviour of the staff. The factors for measuring loyalty includes re visiting the restaurants, telling others about the restaurants and paying a bit premium for the loyalty.

A structured questionnaire is used for the measurement which comprised of 21 questions related to customer satisfaction and loyalty and rest are based on the demographic profile of the customers. Out of total 500 questionnaires sent, 381 returned and found valid for analysis. Data were collected 
from Gujarat region with convenience sampling technique in the last months of 2019. The responses were recorded on 5 point likert scale.

The collected data were analysed through M. S. Excel and S. P. S. S.. The methods adopted for anlaysis are descriptive analysis, correlation analysis, regression analysis, $\mathrm{t}$ test and ANOVA test.

\section{Data Analysis and Discussion.}

Different techniques for analysis of data are adopted as described below.

\subsection{Descriptive analysis.}

For determining reliability of the data, the Chronbach's Alpha is measured which is 0.791 for all factors. The value shows that the data are reliable ( Sun and Zang, 2006 ). The overall skewness calculated is -0.203 with 0.125 as standard error and kurtosis calculated is -0.270 with 0.249 as standard error. The significance for Shapiro - Wilk test resulted as 0.116 which shows the normal distribution of data.

The consumer profile is shown in table I.

Table I.

Demographic profile of consumers.

\begin{tabular}{|c|c|c|c|}
\hline \multicolumn{2}{|c|}{ Gender groups. } & \multicolumn{2}{c|}{ Education groups. } \\
\hline Male. & 203 & Less than graduate. & 65 \\
\hline Female. & 178 & Graduate. & 255 \\
\hline Age groups. (years). & & Post graduate and higher. & 45 \\
\hline Less than 25. & 82 & Professional. & 16 \\
\hline $25-45$. & 187 & Income groups. (p. a.). \\
\hline $46-65$. & 96 & Less than 4,00,000. & 17 \\
\hline Above 65. & 16 & $4,00,001-8,00,000$. & 160 \\
& & & 174 \\
\hline & & $8,00,001-12,00,000$. & 17 \\
\cline { 3 - 4 } & & &
\end{tabular}




\begin{tabular}{|c|c|}
\hline $12,00,001-16,00,000$. & 21 \\
\hline Above 16,00,000. & 09 \\
\hline
\end{tabular}

\subsection{Correlation and regression analysis.}

First, the pearson correlation analysis is done for relating customer satisfaction and customer loyalty among customers of restaurants which is shown in table II..

Table II. Pearson correlation analysis for customer satisfaction and customer loyalty among customers of restaurants.

\begin{tabular}{|ll|r|r|}
\hline \multicolumn{4}{|c|}{ Correlations } \\
\hline & Pearson & $\begin{array}{c}\text { customersati } \\
\text { sfaction }\end{array}$ & loyalty \\
\hline customersatisfactio & Correlation & 1 & $.770^{* *}$ \\
$\mathrm{n}$ & Sig. (2-tailed) & & .000 \\
& $\mathrm{~N}$ & 381 & 381 \\
& Pearson & $.770^{* *}$ & 1 \\
loyalty & Correlation & .000 & \\
& Sig. (2-tailed) & 381 & 381 \\
\hline
\end{tabular}

**. Correlation is significant at the 0.01 level (2-tailed).

It is observed from table II that customer satisfaction and customer loyalty for customers of restaurants are related with each other. Regression analysis is done as shown in table III, IV and V.

Table III. Regression analysis for Customer Satisfaction and Customer Loyalty among customers of restaurants.

\begin{tabular}{|l|l|l|c|c|}
\hline $\begin{array}{l}\text { Mode } \\
1\end{array}$ & $\mathrm{R}$ & $\mathrm{R}$ Square & $\begin{array}{c}\text { Adjusted R } \\
\text { Square }\end{array}$ & $\begin{array}{c}\text { Std. Error of } \\
\text { the Estimate }\end{array}$ \\
\hline
\end{tabular}




\begin{tabular}{|l|r|r|r|r|}
\hline 1 & $.770^{\mathrm{a}}$ & .592 & .591 & 1.48320 \\
\hline
\end{tabular}

a. Predictors: (Constant), customersatisfaction

Table IV. ANOVA for Regression analysis for customer satisfaction and customer loyalty among customers of restaurants.

\begin{tabular}{|c|c|c|c|c|c|c|}
\hline \multicolumn{2}{|c|}{ Model } & $\begin{array}{l}\text { Sum of } \\
\text { Squares }\end{array}$ & df & $\begin{array}{l}\text { Mean } \\
\text { Square }\end{array}$ & $\mathrm{F}$ & Sig. \\
\hline \multirow{3}{*}{1} & Regression & 1210.492 & 1 & 1210.492 & 550.250 & $.000^{\mathrm{b}}$ \\
\hline & Residual & 833.760 & 379 & 2.200 & & \\
\hline & Total & 2044.252 & 380 & & & \\
\hline
\end{tabular}

a. Dependent Variable: loyalty

b. Predictors: (Constant), customersatisfaction

Table V. Coefficients for Regression analysis for customer satisfaction and customer loyalty among online banking customers.

\begin{tabular}{|c|c|c|c|c|c|}
\hline \multirow[t]{2}{*}{ Model } & \multicolumn{2}{|c|}{$\begin{array}{c}\text { Unstandardized } \\
\text { Coefficients }\end{array}$} & \multirow{2}{*}{$\begin{array}{c}\begin{array}{c}\text { Standardized } \\
\text { Coefficients }\end{array} \\
\text { Beta }\end{array}$} & \multirow[t]{2}{*}{$\mathrm{t}$} & \multirow[t]{2}{*}{ Sig. } \\
\hline & B & Std. Error & & & \\
\hline (Constant) & -3.552 & .559 & & -6.349 & .000 \\
\hline $\begin{array}{l}\text { customersatisfactio } \\
\mathrm{n}\end{array}$ & .230 & .010 & .770 & 23.457 & .000 \\
\hline
\end{tabular}

a. Dependent Variable: loyalty

As F calculated is 550.250 which confirms that customer satisfaction is positively related to customer loyalty). The adjusted $\mathrm{R}^{2}$ is 0.591 which shows the customer loyalty as dependent variable on customer satisfaction, but also implies the existence of other factors. The table $\mathrm{V}$ shows the coefficients for the regression.

\subsection{Analysis of demographic groups.}

The $\mathrm{t}$ - test for gender wise comparison and one way ANOVA test for age, education and income wise comparison are calculated which are shown in table VI.

Table VI.

$\mathrm{t}$ test and ANOVA test results for differences in demographic factors among customers of restaurants. 


\begin{tabular}{|c|c|c|c|c|}
\hline Factors & $\begin{array}{c}\text { Gender }(\mathrm{t} \\
\text { test })\end{array}$ & $\begin{array}{c}\text { Age } \\
\text { (ANOVA ) }\end{array}$ & $\begin{array}{c}\text { Education ( } \\
\text { ANOVA ) }\end{array}$ & $\begin{array}{c}\text { Income ( } \\
\text { ANOVA ) }\end{array}$ \\
\hline $\begin{array}{c}\text { Customer } \\
\text { satisfaction. }\end{array}$ & $-8.414^{*}$ & $15.799^{*}$ & 0.860 & $78.887^{*}$ \\
\hline Customer loyalty. & $-7.328^{*}$ & $12.023^{*}$ & 0.770 & $56.459^{*}$ \\
\hline
\end{tabular}

* = significant at 0.05 signifance level.

The $\mathrm{t}$ test results for customer satisfaction and customer loyalty show a significant difference between male and female. Observing means, it can be interpreted that females are more satisfied and loyal compared to males.

The ANOVA test results for customer satisfaction and customer loyalty for customers of restaurants show a significant difference among age groups. To know the specific groups differences of customer satisfaction and customer loyalty among different age groups, post Hoc Tuckey test is done which is shown in table VII.

\section{Table VII.}

Multiple comparison for customer satisfaction and customer loyalty. : tuckey HSD for age groups in customers of restaurants.

\begin{tabular}{|c|c|c|c|c|c|}
\hline $\begin{array}{l}\text { Dependent } \\
\text { Variable }\end{array}$ & $\begin{array}{l}\text { (I) age } \\
\text { ( years ). }\end{array}$ & $\begin{array}{l}(\mathrm{J}) \text { age } \\
(\text { years }) .\end{array}$ & $\begin{array}{c}\text { Mean } \\
\text { Difference (I- } \\
\mathrm{J})\end{array}$ & $\begin{array}{l}\text { Std. } \\
\text { Error }\end{array}$ & Sig. \\
\hline \multirow{12}{*}{$\begin{array}{l}\text { customersat } \\
\text { isfaction }\end{array}$} & \multirow{4}{*}{$\begin{array}{l}\text { Less than } \\
25 \text {. }\end{array}$} & $25-45$ & $5.98767^{*}$ & .97167 & .000 \\
\hline & & $46-65$ & $6.74263^{*}$ & 1.10316 & .000 \\
\hline & & Above 65 . & $6.37805^{*}$ & 2.00501 & .009 \\
\hline & & Less than 25 . & $-5.98767^{*}$ & .97167 & .000 \\
\hline & \multirow[t]{2}{*}{$25-45}$. & $46-65$ & .75496 & .92110 & .845 \\
\hline & & Above 65 . & .39037 & 1.91090 & .997 \\
\hline & \multirow{3}{*}{$46-65$} & Less than 25 . & $-6.74263^{*}$ & 1.10316 & .000 \\
\hline & & $25-45$ & -.75496 & .92110 & .845 \\
\hline & & Above 65 . & -.36458 & 1.98100 & .998 \\
\hline & \multirow{3}{*}{ Above 65 . } & Less than 25. & $-6.37805^{*}$ & 2.00501 & .009 \\
\hline & & $25-45$ & -.39037 & 1.91090 & .997 \\
\hline & & $46-65$ & .36458 & 1.98100 & .998 \\
\hline
\end{tabular}




\begin{tabular}{|c|c|c|c|c|c|}
\hline \multirow{12}{*}{ loyalty } & \multirow{3}{*}{$\begin{array}{l}\text { Less than } \\
25 \text {. }\end{array}$} & $25-45$ & $1.55439^{*}$ & .29369 & .000 \\
\hline & & $46-65$ & $1.86204^{*}$ & .33343 & .000 \\
\hline & & Above 65 . & $2.08079^{*}$ & .60602 & .004 \\
\hline & \multirow{3}{*}{$25-45$} & Less than 25 . & $-1.55439^{*}$ & .29369 & .000 \\
\hline & & $46-65$ & .30765 & .27841 & .687 \\
\hline & & Above 65 & .52640 & .57758 & .799 \\
\hline & \multirow{3}{*}{$46-65$} & Less than 25 . & $-1.86204^{*}$ & .33343 & .000 \\
\hline & & $25-45$ & -.30765 & .27841 & .687 \\
\hline & & Above 65 . & .21875 & .59876 & .983 \\
\hline & \multirow{3}{*}{ Above 65} & Less than 25 . & $-2.08079^{*}$ & .60602 & .004 \\
\hline & & $25-45$ & -.52640 & .57758 & .799 \\
\hline & & $46-65$ & -.21875 & .59876 & .983 \\
\hline
\end{tabular}

$*$ = significant at 0.05 signifance level.

Above table shows the significant difference of customer satisfaction and customer loyalty in customers of restaurants among age group less than 25 years with all other groups. Observing means, it can be interpreted that age group less than 25 years is the most satisfied and loyal group. For education groups, the ANOVA tests shows that there are no significant difference found for customer satisfaction and customer loyalty in customers of restaurants for all education groups.

The ANOVA test results for customer satisfaction and customer loyalty for customers of restaurants show a significant difference among income groups. To know the specific groups differences of customer satisfaction and customer loyalty among different income groups, post Hoc Tuckey test is done which is shown in table VIII.

Table VIII.

Multiple comparison for customer satisfaction and customer loyalty. : tuckey HSD for income groups in customers of restaurants.

\begin{tabular}{|lll|r|r|l|}
\hline $\begin{array}{l}\text { Dependent } \\
\text { Variable }\end{array}$ & $\begin{array}{l}\text { (I) } \\
\text { income }\end{array}$ & $(\mathrm{J})$ income & $\begin{array}{c}\text { Mean } \\
\text { Difference } \\
(\mathrm{I}-\mathrm{J})\end{array}$ & $\begin{array}{c}\text { Std. } \\
\text { Error }\end{array}$ & Sig. \\
\hline & Less & $4,00,001-8,00,000$. & $5.94485^{*}$ & 1.46605 & .001 \\
& than & $8,00,001-12,00,000$. & $13.67546^{*}$ & 1.46037 & .000 \\
customer & $4,00,000$ & $12,00,001-16,00,000$. & $20.31092^{*}$ & 1.87501 & .000 \\
satisfaction &. & Above 16,00,000. & $23.21569^{*}$ & 2.36912 & .000 \\
& $4,00,001$ & Less than 4,00,000. & $-5.94485^{*}$ & 1.46605 & .001
\end{tabular}




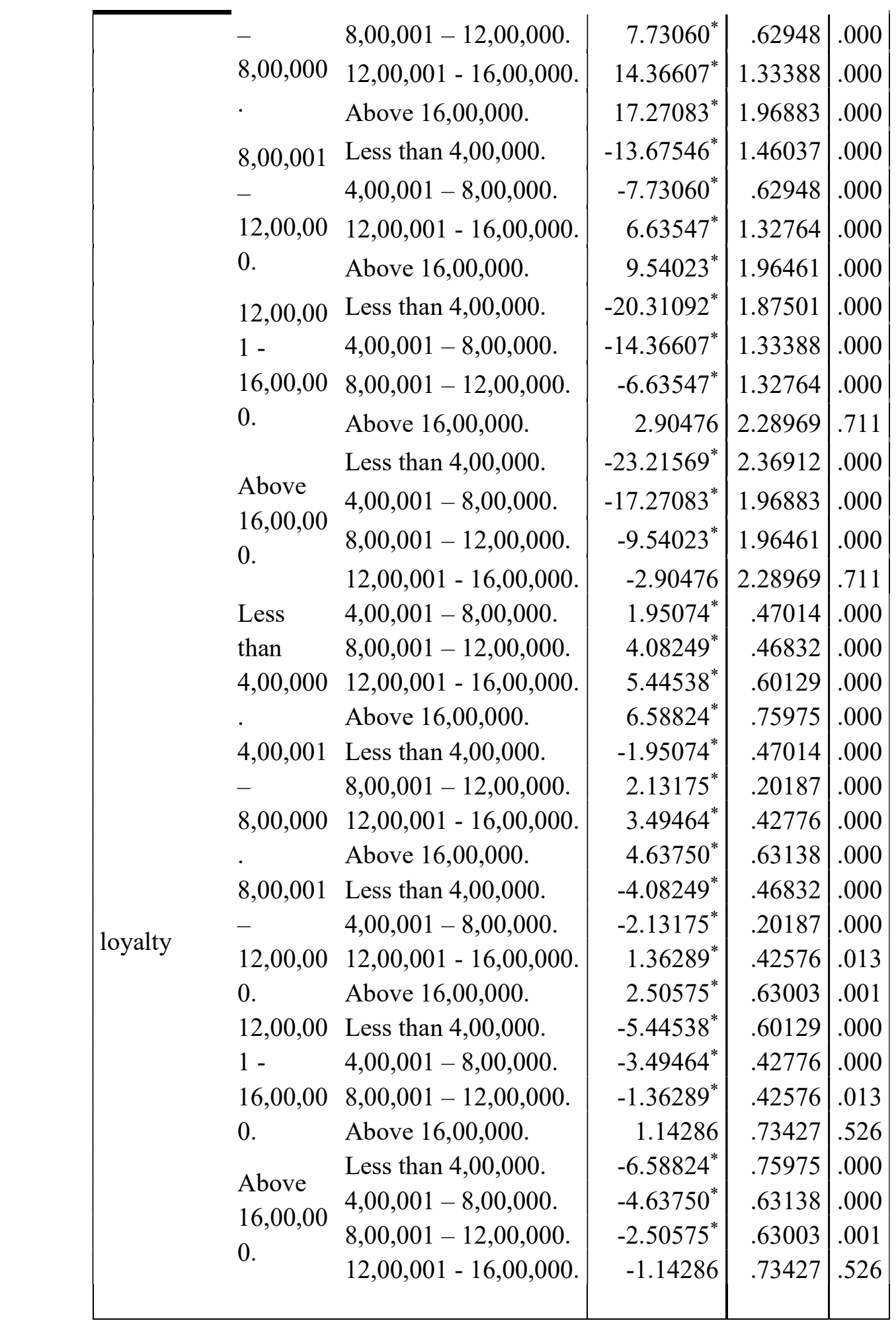

$*=$ significant at 0.05 signifance level.

Above table shows the significant difference of customer satisfaction and customer loyalty in customers of restaurants among all income groups except the group 12,00,001 - 16,00,000 and 
above 16,00,000. Observing means, it can be interpreted that as income increases, the customer satisfaction and customer loyalty in customers of restaurants decreases but, above rs. 12,00,000 income, there are no significant differences of customer satisfaction and customer loyalty in customers of restaurants.

\section{Conclusion.}

The business of restaurants is growing at it's own pace. With growth, competition and levels of competition, there is a need to develop loyalty of which, one important factor is customer satisfaction. The model of customer satisfaction and customer loyalty may provide a hint to marketers to understand and implement and importance of customer satisfaction. The demographic differences may provide a hint to marketers to focus on some demographic groups. The further researchers may get a help and develop the further specific group or specific region or other forms of study. For different types of restaurants or taking other variables further research is possible and may lead to framing strategies for marketers. 


\section{References}

- Auty, S. ( 1992 ). Consumer Choice and Segmentation in the Restaurant Industry, The Service Industries Journal, 12 ( 3 ) : 324 - 339.

- Badiyani J. M., ( 2018 ), Factors affecting consumer satisfaction in restaurants : A study in Gujarat, India. Jyotirmaya Research Journal of Education, 6 ( 1 ), 74 - 82.

- Bailey, R. and Tian, R.G. (2002). Cultural Understanding and Consumer Behavior: A Case Study of Southern American Perception of Indian Food, Journal of American Academy of Business, 2(1):58-65.

- Cengiz E., Ayyildiz H. And Er B., ( 2007 ), Effects of image and advertising efficiency on customer loyalty and antecedents of loyalty, Turkish banks sample. Banks and Bank systems, 2 ( 1$), 56-71$.

- Cheng, K. ( 2005 ), A research on the determinants of consumers' repurchase toward different classes of restaurants in Taiwan, Business Review, vol. 4, no. 2, p. P. 99 - 105.

- Eakuru N. And Mat N. K. N., ( 2008 ), The application of structural equation modeling ( S. E. M. ) in determining the antecedents of customer loyalty in banks in South Thailand, The Business Review, Cambridge, 10 ( 2 ), 129 - 139.

- Fornell, C. and Larcker, D.F. ( 1981 ). Evaluating structural equation models with unobservable variables and measurement error. Journal of Marketing Research, 18, 39 - 50.

- Gupta, S., McLaughlin, E., and Gomez. M. ( 2007 ), Guest satisfaction and restaurant performance, Cornell Hotel \& Restaurant Administration Quarterly, vol. 48, no. 3, p. p. 284 298.

- Han, H.S. and Ryu, K. ( 2009 ). The roles of the physical environment, price perception, and customer satisfaction in determining customer loyalty in the family restaurant industry. Journal of Hospitality \& Tourism Research, 33 ( 4 ), 487 - 510.

- Hensley, R.L. and Sulek, J.M. ( 2004 ). The Relative Importance of Food, Atmosphere and Fairness of Wait: The Case of a Full Service Restaurant, Cornell Hotel and Restaurant Administration Quarterly, 45 ( 3 ) : 235 - 247.

- https://en.wikipedia.org/wiki/Restaurant ( accessed on 15 / 06 / 2020 ).

- https://limetray.com/blog/restaurant-business-in-india/ ( accessed on 15 / 06 / 2020 ). 
- https://www.prnewswire.com/news-releases/global-food-service-market-report-2019-2024market-is-expected-to-reach-a-value-of-us-4-2-trillion-300907559.html ( accessed on 15 / 06 / 2020 ).

- https:/www.statista.com/statistics/681809/global-restaurant-industry-market-size-by-country/ ( accessed on 15 / $06 / 2020)$.

- Hu, H. H. ( 2012 ). The effectiveness of environmental advertising in the hotel industry. Cornell Hospitality Quarterly, 53, $154-164$.

- Hu, H. H., Parsa, H. G. and Self, J. T. ( 2010 ). The dynamics of green restaurant patronage. Cornell Hospitality Quarterly, 51, $344-362$.

- Jang, S. and Namkung, Y. ( 2007 ). Does Food Quality Really Matter in Restaurants? Its Impact on Customer Satisfaction and Behavioral Intentions, Journal of Hospitality and Tourism Research, 31 ( 3 ) : 387 - 410.

- Jin, N., Line, N., and Goh, B. ( 2013 ). Experiential Value, Relationship Quality, and Customer Loyalty in Full-Service Restaurants: The Moderating Role of Gender. Journal of Hospitality Marketing \& Management, 22 ( 7 ), 679 - 700.

- Jones, P. and Merricks, P. ( 1996 ), The Management of Food Service Operations, Wiltshire : Cassel Publishing, Chapter 14.

- Kim, H. ( 2011 ). Service Orientation, Service Quality, Customer Satisfaction, and Customer Loyalty: Testing a Structural Model. Journal of Hospitality Marketing \& Management, 20 ( 6 ), $619-637$.

- Kivela, J. ( 1997 ). Restaurant Marketing: Selection and Segmentation in Hong Kong, International Journal of Contemporary Hospitality Management, 9 ( 3 ) : 116 - 123.

- Knutson, B.J. and Patton, M.E. ( 1993 ). Restaurants can Find Gold among Silver Hair: Opportunities in the 55+ Market, Journal of Hospitality and Leisure Marketing, 1 ( 3 ) : 79 - 90.

- Lewis, R.C. ( 1981 ). Restaurant Advertising: Appeals and Consumers' Intentions, Journal of Advertising Research, 21 ( 5 ) : 69 - 74.

- Mill, R.C. (2007). Restaurant Management: Customers, Operations and Employees. PearsonPrentice Hall.

- Muller, C.C. and Woods, R.H. ( 1994 ). An Expanded Restaurant Typology, Cornell Hotel and Restaurant Administration Quarterly, 35 ( 3 ) : 27 - 37.

- O’Shaughnessy, J. ( 1971 - 1972 ). Selling as an interpersonal influence process. Journal of Retailing, 47, $32-46$. 
- Petrick, J.F. ( 2004 ). First timers' and repeaters' perceived value. Journal of Travel Research, 43 ( 1 ), 29 - 38.

- Sapic S., Kocic M. And Radakovic K. ( 2018 ), The Effect of a Product's Country of Origin on the Customer Loyalty Creation Process. TEME : Casopis Za Drustvene Nauke, 12 ( 4 ), 1297 1317.

- Söderlund, M., and Öhman, N. ( 2005 ), Assessing behavior before it becomes behavior: An examination of the role of intentions as a link between satisfaction and re-patronizing behavior, International Journal of Service Industry Management vol. 16, no. 2, p. p. 169 - 85.

- Soriano, D.R. ( 2002 ). Customers' Expectations Factors in Restaurants: The Situation in Spain, The International Journal of Quality and Reliability Management, 19 ( $8 / 9$ ) : 1055 - 1067.

- Sulek, J., and Hensley, R. ( 2004 ), The relative importance of food, atmosphere, and fairness of wait, Cornell Hotel and Restaurant Administration Quarterly, vol. 45, no. 3, p. p. 235 - 247.

- Sun, H., and P. Zhang.( 2006 ). "Causal Relationships Between Perceived Enjoyment and Perceived Ease of Use: An Alternative Approach.” Journal of the Association of Information Systems 9 ( 7 ), $618-645$.

- Sweeney, J. and Swait, J. ( 2008 ). The effects of brand credibility on customer loyalty. Journal of Retailing and Consumer Services, 15, 179 - 193.

- Voss Glenn B., Parasuraman A. and Grewal Dhruv ( 1998 ), The roles of price, performance and expectations in determining satisfaction in service exchanges, Journal of marketing, Vol. 62 , p. p. $46-61$.

- Wakefield, K.L. and Blodgett, J.G. ( 1994 ). The importance of servicescapes in leisure service settings. Journal of Services Marketing, 8 ( 3 ), 66 - 76.

- Zairi, M., ( 2000 ). Managing Customer Dissatisfaction through Effective Complaint Management Systems. The TQM Magazine, 12 ( 5 ), 331 - 33.

\section{Dr. J. M. Badiyani}

Associate Professor

Department of Business Administration

M. K. Bhavnagar University, Bhavnagar

O. ( 0278 ) 2524216, M. 8200319306,9426460369

E - mail : drjaybadiyani@gmail.com 